\title{
ZRÓWNOWAŻONY ROZWÓJ SEKTORA ROLNEGO NA UKRAINIE W KONTEKŚCIE STRATEGII „EUROPA 2020”
}

\author{
SUSTAINABLE DEVELOPMENT OF THE AGRICULTURAL SECTOR \\ IN UKRAINE IN THE CONTEXT OF THE STRATEGY „EUROPE 2020”
}

\begin{abstract}
This article discusses the basic components of sustainable development of the agricultural sector in the case of Ukraine. The main directions of the harmonization of the determinants of sustainable development in the context of the strategy "Europe 2020" are suggested.
\end{abstract}

Keywords: sustainable development, agricultural sector, Ukraine

JEL classification: O13, Q01

\section{Wstęp}

Globalne tendencje rozwoju współczesnego społeczeństwa pociągają za sobą potrzebę przyjęcia nowego paradygmatu rozwoju społecznego, a co najważniejsze zgodności z nim. Podstawą tego paradygmatu powinna być koncepcja zrównoważonego rozwoju, oparta na fundamentalnych pracach wielu prekursorów, w tym - na doktrynie o noosferze założyciela i pierwszego prezydenta Ukraińskiej Akademii Nauk Władimira Wiernadskiego. Dalsze teorie i praktyka potwierdzają obiektywizm i ważność zastosowania koncepcji ekologiczno-społeczno-ekonomicznego rozwoju. Jak wiadomo, uogólnienia tej koncepcji zostały opracowane podczas światowych szczytów ONZ w latach 1992 i 2002 i uzupełnione w 2012 roku na szczycie znanym jako Rio + 20. W „Deklaracji Milenijnej” państwa członkowskie ONZ przyjęły zobowiązania do osiągnięcia milenijnych celów rozwoju w dziedzinie pokoju i bezpieczeństwa, ochrony środowiska, praw człowieka, demokracji i rządów, ochrony ludności narażonej na ryzyko i tak dalej.

* Prof., Dr., Head of Department of Enterprise, Economics and Personnel Management, Chernivtsi National University, y.lopatynskyi@chnu.edu.ua 


\section{Istota koncepcji zrównoważonego rozwoju}

Koncepcja zrównoważonego rozwoju jest interpretowana na różne sposoby. W artykule trzymamy się klasycznego podejścia, zaproponowanego przez Światową Komisję Środowiska i Rozwoju ONZ jeszcze w 1987 roku, zgodnie z którym zrównoważony rozwój to taki, który zaspokaja potrzeby współczesności, ale bez uszczerbku dla możliwości przyszłych pokoleń do zaspokajania własnych potrzeb $^{1}$. Rozwój ten zapewnia równowagę przede wszystkim trzech komponentów: ekonomicznego, środowiskowego i społecznego. Oczywiście jest to możliwe przy zrównoważeniu interesów wszystkich podmiotów gospodarki narodowej, uwarunkowanych skumulowaniem dodatkowych czynników instytucjonalnych, informacyjnych, innowacyjno-technologicznych, politycznych i innych. To wzajemne powiązanie wielu składników zrównoważonego rozwoju wymaga interdyscyplinarnego podejścia do jego badania.

Zmiany klimatu planety, wzrost ogólnej liczby ludności, a jednocześnie brak oznak zmniejszania ubóstwa, wzmacniają aktualność polityki zrównoważonego rozwoju. Potwierdzeniem aktualności i roli koncepcji zrównoważonego rozwoju jest waga nadawana jej przez niektóre kraje, stowarzyszenia polityczne i ekonomiczne, jak na przykład przez Unię Europejską. Znamiennym przykładem jest nowa europejska strategia na rzecz rozwoju społeczno-gospodarczego w okresie do 2020 roku - Europa 2020. Strategia na rzecz inteligentnego i zrównoważonego rozwoju sprzyjającego właczeniu społecznemu².

\section{Strategia „Europa 2020"}

Jak wiadomo, strategia ma na celu uczynienie Unii Europejskiej ekonomicznie wydajną, a obywateli - bogatszymi. Wysiłki powinny koncentrować się na rozwoju konkurencyjności Unii Europejskiej, produktywności, potencjale wzrostu i ekonomicznego zbliżenia.

Strategia „Europa 2020” skupia się na takich kluczowych czynnikach wzmocnienia gospodarki, jak:

- inteligentny wzrost: rozwój gospodarki opartej na wiedzy i innowacji;

- zrównoważony wzrost: kształtowanie gospodarki w oparciu o odpowiednie wykorzystanie zasobów i przy wzięciu pod uwagę składników środowiska naturalnego, rozwoju tak zwanych ,zielonych” technologii, planów dalszego powstrzymania i niwelowania zmian klimatycznych;

${ }^{1}$ Our Common Future, Report of the World Commission on Environment and Development, Oxford University Press, Oxford 1987, s. 300.

${ }^{2}$ A strategy for smart, sustainable and inclusive growth, European Commission, Brussels, 3 March 2010, COM(2010) 2020 final. 
- kompleksowy wzrost: promowanie zwiększenia poziomu zatrudnienia ludności, osiągnięcie standardów społecznych, zmniejszenie poziomu ubóstwa, tworzenie jednolitego społeczeństwa.

\section{Zrównoważony rozwój na Ukrainie}

W odniesieniu do Ukrainy sytuacja w zakresie zrównoważonego rozwoju nie jest całkowicie zadowalająca. Na poziomie instytucjonalnym brak dokumentów strategicznych, przyjętych w większości krajów Europy, jak na przykład narodowej strategii zrównoważonego rozwoju, czy odrębnej ustawy poświęconej sprawie zrównoważonego rozwoju.

Sytuację komplikuje fakt, że w strukturze rządu państwowego nie ma ministerstwa, agencji lub departamentu odpowiedzialnego wyłącznie za politykę zrównoważonego rozwoju i wypełnienie przez Ukrainę przyjętych na siebie zobowiązań. Stworzone wcześniej organy konsultacyjno-doradcze przy Radzie Bezpieczeństwa Narodowego i Obrony, przy Gabinecie Ministrów, przy Prezydencie Ukrainy, okazały się nieskuteczne i zostały zlikwidowane.

Po podpisaniu umowy stowarzyszeniowej Ukrainy z Unią Europejską jeszcze bardziej pilna stała się kwestia definicji priorytetów i wzorców dla zrównoważonego rozwoju kraju. Bardzo przydatne w tym zakresie może być doświadczenie Polski, bo mieliśmy wspólną przedsiębiorczo-administracyjną przeszłość. Polska osiągnęła bardzo znaczące sukcesy, łącznie ze zmianą zasad funkcjonowania systemu społeczno-gospodarczego. Ukrainie nadal brakuje mechanizmów w celu zapewnienia zrównoważonego rozwoju. Jest to ważne, ponieważ proces wdrażania i realizacji koncepcji zrównoważonego rozwoju jest bezpośrednio powiązany z układami technologicznymi i musi wspierać ich zmiany (przejście na wyższy szczebel rozwoju).

Jako negatywny przykład można tutaj podać poziom zużycia energii (w przeliczeniu na jednostkę produktu krajowego brutto), który na Ukrainie (według szacunków Banku Światowego) jest prawie dwukrotnie wyższy od średniej w Europie, a prawie cztery razy wyższy niż w Polsce, ze względu na niskie tempo restrukturyzacji gospodarki ukraińskiej. Sposobem na rozwiązywanie problemów modernizacji gospodarki Ukrainy mogłyby stać się inwestycje, ale wyniki nie są tutaj bardzo pocieszające. Łączny udział bezpośrednich inwestycji zagranicznych od początku lat 90 . XX w. na Ukrainie jest około trzech razy mniejszy niż w Polsce.

Ogólnie rzecz biorąc, pomimo takich samych możliwości obu krajów na początku transformacji, obecnie poziomy dochodów Ukrainy i Polski znacząco się 
różnią - dochód na jednego mieszkańca Polski prawie czterokrotnie przewyższa odpowiedni dochód na Ukrainie ${ }^{3}$.

Z powyższych względów występuje konieczność przeprowadzenia na Ukrainie reform strukturalnych i instytucjonalnych, wzorowanych na polskich doświadczeniach.

Niski poziom konkurencyjności gospodarki ukraińskiej, strukturalne przełomy, ekstensywny rozwój bazujący na przestarzałej technologii, słabe i nieefektywne wykorzystanie zasobów, niedbanie o środowisko naturalne, niski poziom wydajności i niewystarczające wynagrodzenie za pracę - a w konsekwencji ograniczona ochrona socjalna - utrudniają proces zrównoważonego rozwoju Ukrainy. Ta złożoność uwarunkowań determinuje badania wykonalności procesu zrównoważonego rozwoju z punktu widzenia koncepcji podejścia systemowego, ponieważ proces dynamicznie zmienia właściwości systemu gospodarczego i ma charakter nieliniowy. Tak więc przejście do koncepcji zrównoważonego rozwoju wymaga z jednej strony innowacji i inwestycji, z drugiej - skutecznego współdziałania zainteresowanych stron.

\section{Sektor rolny na Ukrainie}

Jest to szczególnie aktualne w odniesieniu do sektora rolnego na Ukrainie, który ma silną pozycję w strukturze gospodarki narodowej, tworząc ponad $9 \%$ PKB (w 2013 roku), dając zatrudnienie 17,5\% pracującym i stanowiąc ponad jedną czwartą eksportu krajowego ${ }^{4}$. W trudnych warunkach 2014 roku, rolnictwo Ukrainy było jedynym sektorem, który wykazał pozytywną dynamikę. Jednak wzrost ten jest w dużej mierze ekstensywny.

Z drugiej strony, ukraińskie rolnictwo odznacza się dość istotnym udziałem w zanieczyszczaniu środowiska naturalnego, demonstrując negatywne efekty zewnętrzne -,externalities”. Udział sektora rolnego w zanieczyszczaniu i degradacji środowiska naturalnego stanowi więcej niż jedną trzecią całkowitego destrukcyjnego wpływu. Zasoby tego sektora są bardzo wyczerpane, a on sam potrzebuje znacznej modernizacji.

Ze względu na emisję substancji szkodliwych z sektora rolnego obserwowano znaczne pogorszenie stanu gruntów rolnych na Ukrainie, co objawia się następująco: zniszczeniem struktury gleby, erozją wodną i wietrzną, zakwaszeniem, zasoleniem. Ujemny bilans odżywczych składników w ziemi dotyka znacznego

3 Украӥна: проблеми та перспективи розвитку приватного сектору, Світовий банк, 2014, s. 104.

${ }^{4}$ Статистичний щзорічник України за 2013 рік, Державна служба статистики України 2014, s. 534; Сільське господарство України, 2013, Статистичний збірник, Державна служба статистики України 2014, s. 390. 
procenta gruntów uprawnych. Do tego dochodzi dominacja monokultur, zmniejszenie bioróżnorodności, brak płodozmianu, itp. Nadmierna chemizacja rolnictwa zanieczyszcza tak glebę, jak i wodę. W związku z tym ekosystem jest używany jako surowcowy dodatek do procesu produkcyjnego.

Charakteryzując system produkcyjny, należy podkreślić asymetryczną strukturę ukraińskiego sektora rolnego, w którym można wyodrębnić trzy grupy producentów:

- ponad 4 mln gospodarstw prywatnych, na które, pomimo zmniejszenia, przypada $46 \%$ produkcji brutto rolnictwa Ukrainy (według statystyk 2013 roku);

- małe i średnie przedsiębiorstwa wśród gospodarstw rolnych, które powinny służyć jako podstawa dla zrównoważonego rozwoju, choć tak się nie stało;

- duże przedsiębiorstwa rolne (agroholdingi), które wykazują wzrost gospodarczy, konsolidując grunty i inne zasoby. W ten sposób pod kontrolą agroholdingów pozostaje prawie $28 \%$ użytków rolnych będących w użytkowaniu przez przedsiębiorstwa rolne 5 .

Pierwsza i druga grupa zależą od władzy ekonomicznej dostawców zasobów i kupców produkcji rolnej, wspierających jednostek infrastruktury, takich jak banki $\mathrm{i}$ inne. Tak więc pierwsza grupa nie tylko nie posiada zasobów na rzecz zrównoważonego rozwoju, ale $\mathrm{w}$ większości przypadków pewnie w ogóle o takim procesie nie słyszała. Jeśli gospodarstwa z tej grupy pracują na rzecz zrównoważonego rozwoju, to przede wszystkim ze względu na brak funduszy na nawozy mineralne i środki chemiczne. W tym samym czasie osiągane wyniki gospodarcze i parametry społeczne są dość niskie. Ludność wiejska na Ukrainie jest najbiedniejszym segmentem społeczeństwa, o najniższym poziomie edukacji, ochrony socjalnej ludności, najgorszych warunkach życia, wysokiej śmiertelności i tak dalej.

Producenci z trzeciej grupy (agroholdingi) mają zdolność do zapewnienia warunków dla zrównoważonego rozwoju, ale głównie koncentrują się na ekonomicznych aspektach działalności gospodarczej, specjalizując się przede wszystkim w eksporcie zboża i kultur technicznych. Ta grupa jest zdolna wywierać ekonomiczny wpływ na sytuację w sektorze agrarnym gospodarki narodowej, co czyni dla własnej korzyści.

Zauważmy, że zgodnie z moratorium na zakup-sprzedaż ziemi rolnej na Ukrainie, znaczne obszary gruntów są dzierżawione, co nie motywuje dzierżawców do właściwego wykorzystywania gruntów, przy braku odpowiednich mechanizmów to wymuszających. Na przykład, według statystyk z 2013 roku ponad $15 \%$ przedsiębiorstw w ogóle nie posiadało gruntów rolnych, a prawie połowa przedsiębiorstw była właścicielami gruntów rolnych do 50 hektarów (na jedno

${ }^{5}$ Сільське господарство Украӥни, 2013, Статистичний збірник, Державна служба статистики України, 2014, s. 390. 
przedsiębiorstwo), posiadając razem około 3\% obszaru wszystkich gruntów rolnych ${ }^{6}$.

Wyraźnie określone i regulowane prawa własności gruntów spełniają także funkcję społeczną, dając bardzo silne bodźce właścicielom i dzierżawcom, skłaniają ich do stałego wykorzystywania gruntów, wdrażania zaawansowanych systemów własności ziemi, dywersyfikacji systemów rolnictwa, szerszego wykorzystania możliwości biologicznych i genetycznych roślin i zwierząt, optymalizacji wykorzystania nawozów mineralnych i chemicznych pestycydów. Aby to osiągnąć, Ukraina musi zakończyć reformę rolną, która będzie zachęcać podmioty gospodarcze do inwestowania w ziemie dzierżawione i własne, chronione przez prawo własności.

Wśród elementów zrównoważonego rozwoju sektora rolnego warto zauważyć poprawę zarządzania zasobami naturalnymi, zmniejszenie uzależnienia produkcji rolnej od zasobów. Na poziomie jednostek produkcyjnych jest ważne, aby zachęcić je do rozwoju nowoczesnego, zrównoważonego rolnictwa, biorącego pod uwagę także potrzebę ochrony środowiska. W tym powinno pomóc upowszechnianie stosowania metod ekologicznych, szczególnie produkcji organicznej i wykorzystania biotechnologii. Ważną rolę spełnia wprowadzenie lepszej infrastruktury rolnej, w tym obecność czynnych służb doradczych.

W systemie kompleksowych działań w celu wzmocnienia zrównoważonego rozwoju sektora rolnego znaczącą rolę odgrywa rząd, który tworzy i wdraża strategie i plany rozwoju, daje odpowiednie narzędzia do stymulowania i wpływu, oceny ryzyka i wprowadzania systemów wczesnego ostrzegania, zapewnia kontrolę jakości żywności i gwarancji bezpieczeństwa żywności w kraju.

Swoje miejsce w strukturze ma też społeczność wiejska, która koordynuje rozwój lokalnych organizacji i buduje możliwości udziału ludzi w zarządzaniu rozwojem rolnictwa.

\section{Wnioski i rekomendacje}

Celem dalszym ukraińskich reform agrarnych jest osiągnięcie standardów europejskich, których rola w Ukrainie jest uznana. Jak pamiętamy, na początku procesu integracji polscy rolnicy najbardziej martwili się o skutki przyłączenia do wspólnego rynku rolnego. W 2014 roku - jubileuszowym od czasu włączenia polskiego sektora rolnego do Wspólnej Polityki Rolnej (WPR) Unii Europejskiej - okazało się, że w rzeczywistości to oni wygrali najwięcej; w rolnictwie zaszły poważne zmiany strukturalne i organizacyjne. Doświadczenie Polski jest bardzo pouczające dla perspektyw ukraińskiego sektora rolnego.

\section{Tamże.}


Strategia „Europa 2020” odnosi się nie tylko do krajów UE, ale również służy jako dobry wzór dla państw-kandydatów do UE i sąsiadów, którzy mogą kształtować swoją politykę w oparciu o proponowane przez strategię cele i zadania. Reformy to droga do zrównoważonego rozwoju. Jest o tym mowa w opublikowanych przez Prezydenta Ukrainy Petra Poroszenko tezach „Strategii 2020” w zakresie rozwoju Ukrainy, gdzie zwraca się uwagę na potrzebę przełamania neofeudalnego modelu polityczno-gospodarczego, którego szkodliwe oddziaływanie odczuwalne jest także w rolnictwie, na przykład w kwestii dostępu do państwowych zasobów rozwoju rolnictwa. Powinien zapanować porządek otwartego dostępu, który wprowadzi równe warunki dla wszystkich uczestników rynku. Końcowe plany są ambitne - wniosek o członkostwo w UE w 2020 roku.

Ukraina ogromnie potrzebuje realizacji takich planów. Według szacunków w ukraiński sektor rolniczy powinno się włożyć 70 mld USD na modernizację, wtedy za siedem lat Ukraina może stać się światowym liderem w produkcji rolno-spożywczej. Ostatecznie jednak idea zrównoważonego rozwoju nadal pozostaje raczej kwestią ideologiczną, polityczną, organizacyjnym priorytetem. Oczywiście koncepcja zrównoważonego rozwoju nie jest celem sama w sobie, lecz kierunkiem, w którym konsekwentnie trzeba iść.

\section{Bibliografia}

A strategy for smart, sustainable and inclusive growth, European Commission, Brussels, March 3.2010.COM(2010) 2020 final.

Our Common Future, Report of the World Commission on Environment and Development, Oxford University Press, Oxford 1987.

Сільське господарство України. 2013, Статистичний збірник, Державна служба статистики України, 2014.

Статистичний щорічник України за 2013 рік, Державна служба статистики України, 2014.

Україна: проблеми та перспективи розвитку приватного сектору, Світовий банк, 2014.

\section{Streszczenie}

W artykule omówiono podstawowe elementy zrównoważonego rozwoju sektora rolnego na przykładzie Ukrainy. Zaproponowano główne kierunki harmonizacji uwarunkowań zrównoważonego rozwoju w kontekście strategii „Europa 2020”.

Słowa kluczowe: zrównoważony rozwój, sektor rolny, Ukraina

Numer klasyfikacji JEL: O13, Q01 


\section{Сталий розвиток аграрного сектора України в контексті стратегії "Свропа 2020"}

У статті розглядаються основні складові сталого розвитку аграрного сектора на прикладі України. Запропоновано основні напрями гармонізації детермінант сталого розвитку в контексті стратегії “Європа 2020”.

\section{Устойчивое развитие аграрного сектора Украины в контексте стратегии} "Европа 2020"

В статье рассматриваются основные составляющие устойчивого развития аграрного сектора на примере Украины. Предложены основные направления гармонизации детерминант устойчивого развития в контексте стратегии “Свропа 2020". 